\title{
Th17/Treg cell expression in children with primary nephritic syndrome and the effects of ox-LDL on Th17/Treg cells
}

\author{
Y.Y. Li' ${ }^{1,2}$, S.G. Wei ${ }^{2}$, X. Zhao ${ }^{3}$, Y.Z. Jia' ${ }^{2}$, Y.F. Zhang ${ }^{2}$ and S.Z. Sun ${ }^{1}$ \\ ${ }^{1}$ Department of Pediatric Nephrology and Rheumatism and Immunology, \\ Provincial Hospital Affiliated to Shandong University, Jinan, China \\ ${ }^{2}$ Department of Pediatrics, Yidu Central Hospital of Weifang, Qingzhou, China \\ ${ }^{3}$ Department of Interventional Radiotherapy, Yidu Central Hospital of Weifang, \\ Qingzhou, China
}

Corresponding author: S.Z. Shun

E-mail: kijjdhfehinjk@126.com

Genet. Mol. Res. 15 (2): gmr.15027669

Received September 17, 2105

Accepted February 11, 2016

Published June 10, 2016

DOI http://dx.doi.org/10.4238/gmr.15027669

\begin{abstract}
To investigate the role of T-helper cells/Treg (Th17/ Treg) and morbidity factors related to primary nephritic syndrome (PNS) in children, as well as the influence of ox-low density lipoprotein (ox-LDL) on Th17/Treg expression in children with PNS. To clarify the pathogenesis of PNS in children, 50 children with PNS treated in our hospital were enrolled in the study group. Additionally, 20 healthy children who came to our hospital for physical examination during the same period were enrolled in the control group. Th17 and Treg cells in children belonging to the two groups were detected by flow cytometry; the numbers of Th17/Treg cells in peripheral blood mononuclear cells at different concentrations of ox-LDL were detected simultaneously. Ox-LDL can affect the number of Th17/Treg cells in peripheral blood mononuclear cells, and both cell types decreased with increasing concentration of ox-LDL, with the numbers being significantly lower in the control group. However, the decrease in the number of Th17
\end{abstract}


cells was statistically insignificant $(\mathrm{P}>0.05)$, whereas the decrease in Treg cells was more obvious and statistically significant $(\mathrm{P}<0.05)$. The effect of ox-LDL the number of Treg cells was stronger than that on Th17 cells. We concluded that the imbalance of Th17/Treg cells influenced by high and low ox-LDL concentrations in children with PNS might be the immunological basis of the disease.

Key words: Ox-LDL; Th17/Treg cells; Primary nephritic syndrome; Children

\section{INTRODUCTION}

Nephrotic syndrome (NS) is characterized by the clinical manifestation of proteinuria (h>3.5 g/L within $24 \mathrm{~h}$ ), low plasma albumin ( $<30 \mathrm{~g} / \mathrm{L}$ within $24 \mathrm{~h})$, hyperlipidemia, and edema, which can be both primary and secondary. Proteinuria and hypoalbuminemia are the two critical indicators required for diagnosis (Qiu et al., 2015; Yang and Zhang, 2015). PNS is more common in children (Lu et al., 2014). Muntner et al. (2010) believed that individuals with chronic kidney disease could be most effectively treated in childhood. However, the specific etiology and mechanism of PNS in children remains unclear. The clinical data and information suggest that corticosteroids and immunosuppressants can relieve PNS symptoms in children. However, during childhood, the body and organs are still developing and tolerance to these drugs is low; side effects and adverse reactions of the drugs are most obvious in children. This disease can frequently recur in patients once it progresses to later stages, which can in severe cases lead to chronic glomerular sclerosis (Paul et al., 2014; Working Group for National Survey on Status of Diagnosis and Treatment of Childhood Renal Diseases, 2014; Ezaki et al., 2015; Geng et al., 2015; Chen and Xia, 2015; Yang and Zhang, 2015). CD4+ cells can be classified into T helper cell 1 (Th1), Th2, Th17, and CD4+CD25+ regulatory cells (Treg) in vitro (Wang et al., 2010, 2013). Physiologically, there is a relatively stable dynamic equilibrium between Th17 and Treg cells, which is an antagonistic relationship. Studies have shown that there is an increase in the number of Th17 cells and/or decrease in Treg cells in patients with inflammatory and autoimmune diseases (Ramesh et al., 2014; Nie et al., 2015). The present study aimed to investigate the role of Th17 and Treg cells and related factors in the incidence and development of PNS in children. We observed the expression levels of both cell types in the peripheral blood and tissues of children with PNS to clarify its pathogenesis. Our results could prove useful for developing novel treatments for PNS in children in the future.

\section{PATIENTS AND METHODS}

\section{Subjects}

The children (50 cases) with PNS admitted to the Provincial Hospital Affiliated to Shandong University from February 2013 to February 2015 were enrolled in the study group, including 40 cases of boys and 10 cases of girls, aged from 2 to 5 years old, with the average age being $3.4 \pm 0.5$ years. These children met all the inclusion criteria: 1) The diagnostic criteria for PNS prepared by the kidney disease committee of the Pediatrics branch of the Chinese 
Medical Association in 2001 (Wang et al., 2010); 2) Glucocorticoids or immunosuppressive therapy not used 30 days prior to admission; 3 ) No secondary kidney disease (such as lupus nephropathy, purpura nephropathy or congenital kidney disease etc.); 4) No other systemic viscera syndrome; 5) Signed informed consent. The healthy children (20 cases) who came to our hospital for physical examination during the same period were enrolled in the control group, including 16 cases of boys and 4 cases of girls, aged from 2 to 6 years old, with the average age being $3.1 \pm 1.0$ years.

\section{Materials and equipment}

The following materials and equipment were used: RPMI-1640 medium (Roswell Park Memorial Institute); human lymphocyte separation medium (Shanghai Yanjin Biological Technology Co., LTD.); fetal bovine serum (Shanghai Bioleaf Technology Co., LTD.); two-step immunohistochemical detection kit (HRP-polymer anti rabbit, Wuhan Boster Biological Engineering Co., LTD.); Th17 cells Fix\&perm ${ }^{\circledR}$ permeabilization medium and fixation medium, Treg cells Fix\&perm ${ }^{\circledR}$ permeabilization medium and fixation medium (Shanghai Yingbiotech Co., LTD.); penicillin and streptomycin (Zhuhai Haililai Enterprise Co., LTD.); DAB chromogenic agent (Shanghai Hengyuan biological technology Co., LTD.); neutral balsam (Beijing Solarbio technology co., LTD.); anhydrous ethanol, chloroform (Jiangsu Dongcheng Biological Technology Group Co., LTD.); cell culture box (Shanghai Lishen Scientific Instrument Co., LTD.); table-model high speed centrifuge (Hemo Instrument Technology (Shanghai) Co., LTD.); electronic analytical balance (Hebi Aowei Electronic Technology Co., LTD.); thermostatic water tank and sample injector (Shenzhen Libang Precision Instruments Co., LTD.); ultra-thin slicing machine (RMC co., LTD., USA).

\section{Detection of Th17 cells using flow cytometry}

We collected $5 \mathrm{~mL}$ venous blood from all subjects in the fasting state, and $3.0 \mathrm{x}$ $10^{9} / \mathrm{L}$ peripheral blood mononuclear cells were centrifugally separated. Approximately 2 $\mathrm{mL}$ blood was transferred to a 24-well plate, and then mixed well with $60 \mu \mathrm{g} / \mathrm{L}$ Buddha wave ester, $1.0 \mu \mathrm{M}$ Monensin, and $100 \mu \mathrm{M}$ streptin. The mixtures were cultured in the incubator with $5 \% \mathrm{CO}_{2}$ at $37^{\circ} \mathrm{C}$ for $5 \mathrm{~h}$. Next, the cell suspension was transferred to a 2-mL sterile Eppendorf (E P) tube, which was centrifuged at $3000 \mathrm{rpm}$ for $6 \mathrm{~min}$. The supernatant was discarded, and the cells were washed with phosphate buffer saline (PBS) twice to remove the reserve liquid. Then, we added $15 \mu \mathrm{L} \mathrm{CD} 4$ and IL17a antibodies, and incubated the cells in the dark for $30 \mathrm{~min}$. After washing with PBS twice, we added $50 \mu \mathrm{L}$ fixation medium, incubating the cells in the dark for $10 \mathrm{~min}$ at $5^{\circ} \mathrm{C}$. The supernatant was discarded and we added $1 \mathrm{~mL}$ permeabilization medium and then centrifuged the cells at $3000 \mathrm{rpm}$ for $5 \mathrm{~min}$. The supernatant was discarded again and the cells were washed with PBS twice, and divided into two equal parts: to one part we added $5 \mu \mathrm{L}$ phycoerythrin antiinterleukin-17 (PE anti-IL-17) and to the other part we added the corresponding isotype control phycoerythrin immunoglobulin G1 (PE-IgG1). These mixtures were incubated in the dark for $30 \mathrm{~min}$. After washing the cells with PBS twice and resuspending them in 1.0 $\mathrm{mL}$ PBS, we conducted the flow cytometry analysis. 


\section{Detection of Treg cells using flow cytometry}

We drew $2 \mathrm{~mL}$ of the reserve liquid and added $15 \mu \mathrm{L} \mathrm{CD} 4$ (1:100) and CD25 (1:100) antibodies, incubating the cells in the dark for $30 \mathrm{~min}$ at $37^{\circ} \mathrm{C}$. Next, the cells were washed twice with PBS, and $50 \mu \mathrm{L}$ fixation medium was added. The cells were again incubated in the dark for $10 \mathrm{~min}$ at $5^{\circ} \mathrm{C}$. The supernatant was discarded and we added the permeabilization medium, followed by centrifugation at $3000 \mathrm{rpm}$ for $5 \mathrm{~min}$. The supernatant was discarded again and the cells were washed twice with PBS. Next, they were divided into two equal parts: to one part, $5 \mu \mathrm{L}$ PE-anti- Foxp3 was added, and to the other part, we added the same amount of the corresponding PE-IgG 1. The mixtures were kept in the dark for 30 min and then washed twice with PBS. Finally, the cells were resuspended in $1.0 \mathrm{~mL}$ PBS for flow cytometry analysis.

\section{Effect of ox-LDL on the Th17/Treg population in total peripheral blood mononuclear cells}

We collected $5 \mathrm{~mL}$ venous blood from subjects in the control group in the fasting state. The samples were transferred to a 24-well plate, seeded at a density of $1 \times 10^{6}$ cells per well. The experimental set up included the following four groups: a blank group with an ox-LDL concentration of $0.0 \mu \mathrm{g} / \mathrm{mL}$, and three intervention groups with concentrations of $0.1,1.0$, and $10.0 \mu \mathrm{g} / \mathrm{mL}$. After incubation in $5 \% \mathrm{CO} 2$ at $37^{\circ} \mathrm{C}$ for one day and night, we conducted flow cytometry analysis of Th17 and Treg cells.

\section{Statistical analysis}

In this study, the SPSS 18.0 statistical software was used for data analysis. The data are reported as means \pm standard deviation. Analysis of variance was used to compare the multi-group differences. Fisher's least significant difference (LSD-t test) was used to analyze the pairwise comparison. $\mathrm{P}<0.05$ indicated that the difference was statistically significant.

\section{RESULTS}

\section{Expression of T cells with IL-17 in the two groups}

The results demonstrated that compared with the control group, the expression of

Th17 cells in the peripheral blood samples from the study group significantly increased (Figure 1); the percentage of cells in the samples from the study group was $2.7 \pm 0.1 \%$, whereas that in the samples from the control group was $0.7 \pm 0.1 \%$. Moreover, the difference between the two groups was statistically significant $(t=14.201, P<0.01$, Table 1$)$.

Additionally, we showed that compared with the control group, the expression of Treg cells in the peripheral blood samples from the study group significantly decreased (Figure 2); the percentage of cells in the samples from the study group was $1.7 \pm 0.1 \%$, whereas that in the samples from the control group was $5.8 \pm 0.1 \%$. The difference was statistically significant $(\mathrm{t}=12.11, \mathrm{P}<0.01$, Table 2$)$. 

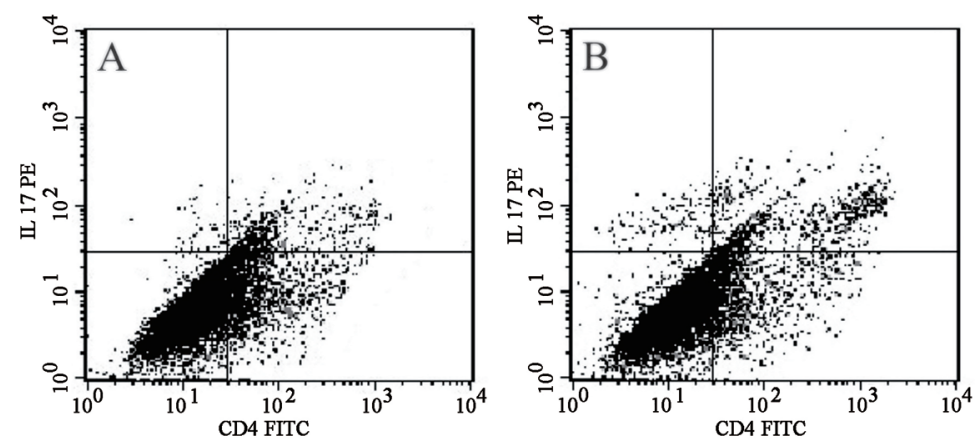

Figure 1. Detection of Th 17 cells in the two groups (A: control group; B: study group) by flow cytometry.

Table 1. Expression of Th17 cells in the two groups (N, \%).
\begin{tabular}{|c|c|c}
\hline Group & Cases & Th17 cells (CD4 + IL17a) \\
\hline Control & 20 & $0.7 \pm 0.1$ \\
\hline Study & 50 & $2.7 \pm 0.1^{*}$ \\
\hline
\end{tabular}

Compared with that in the control group, $* \mathrm{P}<0.01$.
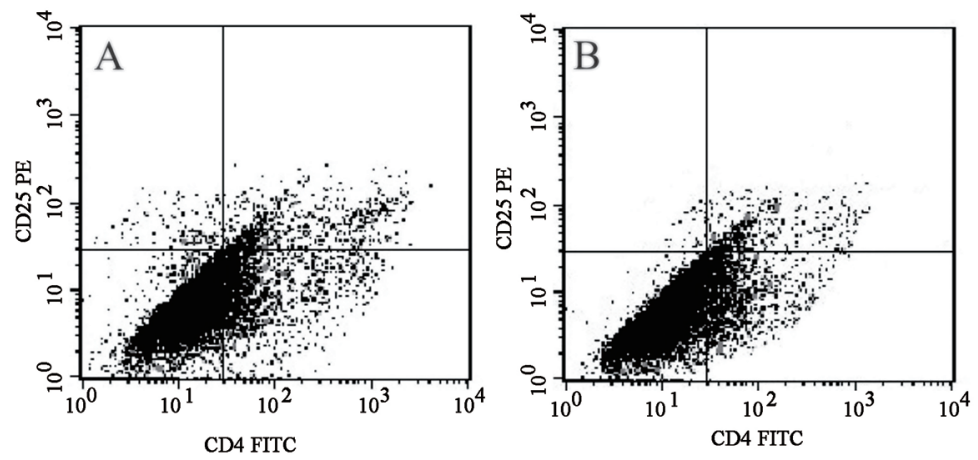

Figure 2. Detection of Treg cells in the two groups (A. control group; B. study group) by flow cytometry.

Table 2. Expression of Treg cells in the two groups (N, \%).

\begin{tabular}{l|c|c}
\hline Group & Cases & Treg(CD4+CD25) \\
\hline Control group & 20 & $5.8 \pm 0.1$ \\
\hline Study group & 50 & $1.7 \pm 0.1^{*}$ \\
\hline
\end{tabular}

Compared with that in the control group, $* \mathrm{P}<0.01$.

\section{Effects of ox-LDL on the number of Th17/Treg cells in total peripheral blood mononuclear cells}

Our results suggested that ox-LDL concentration affected Th17/Treg cells numbers in peripheral blood mononuclear cells. Both cell types decreased in number with the increase in ox- LDL concentration. However, the numbers of both cell types were significantly lower in the control group. The statistical results indicated that the difference in the decrease in number 
of Th17 cells at varying concentrations was insignificant $(\mathrm{P}>0.05)$. On the other hand, Treg cells decreased markedly and the comparisons among groups were statistically significant ( $\mathrm{P}$ $<0.05$; Table 3).

Table 3. Effects of ox-LDL on the number of Th17/Treg cells in peripheral blood mononuclear cells ( $\mu \mathrm{g} / \mathrm{mL}, \%)$.

\begin{tabular}{l|c|c|c}
\hline Group & ox- LDL concentration & Th17 cells & Treg cells \\
\hline Blank & 0.0 & $0.91 \pm 0.01$ & $5.23 \pm 0.01$ \\
\hline Intervention & 0.1 & $0.74 \pm 0.01$ & $4.34 \pm 0.03$ \\
\hline & 1.0 & $0.63 \pm 0.02$ & $3.68 \pm 0.01$ \\
\hline & 10.0 & $0.41 \pm 0.01$ & $2.60 \pm 0.01$ \\
\hline F value & & 3.09 & 11.23 \\
\hline P value & & $>0.05$ & $<0.05$ \\
\hline
\end{tabular}

\section{DISCUSSION}

Th17 is a newly discovered T cell subset which can secrete IL-17 and plays an important role in autoimmune diseases and host defense responses (Lu et al., 2014; Said et al., 2014; Guitart et al., 2015). Some studies have shown that the incidence of PNS is related with T cells, especially with Th1/Th2 cell subsets (Hu et al., 2015). Th17 cells are different from Th1/Th2 cell subsets, and their differentiation as well as developmental mechanisms are also distinct from those of other types of cell populations (Huang et al., 2014; Munari et al., 2014). The studies of Di Meglio et al. (2011) showed that IL-23 is prominently involved in immune diseases induced by Th17. Studies on the TGF- $\beta$ R mutation and IL-6-/- rats showed that these mice had no Th17 cells (Zhang et al., 2013), indicating there was strong tolerance to experimental autoimmune encephalomyelitis. From this we can deduce that IL-6 and TGF-B have an obvious effect on the differentiation of Th17 cells. Reports suggest that interleukin factors such as IL-23, may be involved in and promote the differentiation of Th17 cells in humans (Zhang et al., 2014b; Kashem et al., 2015). Bartlett and Million (2015) believed that the proportion of Th17 cells in the peripheral blood of children with PNS increased. This is accompanied by a significant increase in the expression of IL-23 and IL-17 in the peripheral blood mononuclear cells, suggesting that the abnormal expression of Th17 is closely related with the onset of PNS.

Treg cells as a class of CD4 $+T$ cells have dual roles of immune activation and immune suppression (Zhang et al., 2014a), which can inhibit the function of the body's own T cells through the intervention of anti-inflammatory factors, and balance the immune response in vivo (Theron et al., 2013). Recent data has shown that growth factor- $\beta 1$ (GF- $\beta 1$ ) can promote the differentiation of Treg cells (Wang et al., 2010). Experimental animal studies suggest that Treg cells can reduce the urinary protein content in focal segmental glomerular sclerosis (FSGS) rats, and play a protective role in graft rejection nephritis (Gorantla et al., 2010). Shao et al. (2009) believed that Th17 and Treg cells have an obvious effect on the maintenance of inflammatory and immune homeostasis. Reducing Treg cells and increasing Th17 cells can lead to the incidence of renal allograft rejection, lupus nephropathy, immunoglobulin A(IgA) nephropathy, hyperplasia of glomerular nephritis, nephritis, acute coronary comprehensive syndrome, allergic purpura, and other diseases (Turner et al., 2010; Yu et al., 2013; ZambranoZaragoza et al., 2014; Feng et al., 2015; Tabarkiewicz et al., 2015) .

This study showed that compared with the control group, the expression of Th17 cells in the peripheral blood from PNS patients significantly increased (Figure 1); the percentages of cells in the study and control groups were $2.7 \pm 0.1$ and $0.7 \pm 0.1 \%$, respectively. The 
differences between the two groups were statistically significant. Moreover, compared with the control group, the expression of Treg cells in the peripheral blood of patients in the study group significantly decreased; the percentages of cells in the study and control groups were $1.7 \pm 0.1$ and $5.8 \pm 0.1 \%$, respectively. The difference between the two groups was also statistically significant, indicating that Th17 cell expression increased and Treg cell expression decreased. Such a physiological disturbance can cause an immune imbalance which may lead to severe proteinuria in children with PNS. Studies have suggested that an important pathophysiological abnormality in children with PNS is hyperlipidemia, which can accelerate renal disease progression (Ruan et al., 2012; Working Group for National Survey on Status of Diagnosis and Treatment of Childhood Renal Diseases, 2014). Excessive LDL produced due to hyperlipidemia can be converted into ox- LDL with the help of lipoxygenase and critical reactive oxygen group modifications. Furthermore, ox-LDL can accelerate apoptosis of Treg cells (Li et al., 2014). Although the statistical results showed that the number of Th17 cells decreased, the differences among concentration groups were not statistically significant. On the other hand, Treg cells decreased markedly, with statistically significant differences among groups. This study suggested that ox-LDL concentration affected the number of Th17/Treg cells in total peripheral blood mononuclear cells. Both cell types decreased with the increase in ox-LDL concentration, with the number of cells significantly lower in the control group. The effect of ox-LDL is stronger on Treg cells than that on Th17 cells in the peripheral blood of children due to the different expression of Th17 or Treg cells between patients with minimal lesion nephrotic syndrome and patients with non-minimal change nephrotic syndrome.

In summary, the inhibitory effect of ox-LDL on the number of Treg cells is stronger than that on Th17 cells. The imbalance of Th17/Treg cells in children with PNS may be responsible for the immuno-pathology of the disease.

\section{REFERENCES}

Bartlett HS and Million RP (2015). Targeting the IL-17-T(H)17 pathway. Nat. Rev. Drug Discov. 14: 11-12. http://dx.doi. org $/ 10.1038 / \mathrm{nrd} 4518$

Chen $\mathrm{C}$ and Xia Y (2015). [Influential factors for theraputic effect of steroid on adult primary nephrotic syndrome]. Zhong Nan Da Xue Xue Bao Yi Xue Ban 40: 78-82.

Di Meglio P, Di Cesare A, Laggner U, Chu CC, et al. (2011). The IL23R R381Q gene variant protects against immunemediated diseases by impairing IL-23-induced Th17 effector response in humans. PLoS One 6: e17160. http://dx.doi. org/10.1371/journal.pone.0017160

Ezaki J, Hashimoto K, Asano T, Kanda S, et al. (2015). Gonadal tumor in Frasier syndrome: a review and classification. Cancer Prev. Res. (Phila.) 8: 271-276.http://dx.doi.org/10.1158/1940-6207.CAPR-14-0415

Feng H, Yin J, Han YP, Zhou XY, et al. (2015). Sustained changes of Treg and Th17 cells during interferon- $\alpha$ therapy in patients with chronic Hepatitis B. Viral Immunol. 28: 412-417. http://dx.doi.org/10.1089/vim.2015.0024

Geng HY, Cao L, Wang W, Chen DK, et al. (2015). [A prospective, randomized, controlled clinical study of Huai Qi Huang granules in treatment of childhood primary nephrotic syndrome]. Zhongguo Dang Dai Er Ke Za Zhi 17: 31-34.

Gorantla VS, Schneeberger S, Brandacher G, Sucher R, et al. (2010). T regulatory cells and transplantation tolerance. Transplant. Rev. (Orlando) 24: 147-159. http://dx.doi.org/10.1016/j.trre.2010.04.002

Guitart J, Martinez-Escala ME, Deonizio JM, Gerami P, et al. (2015). CD30(+) cutaneous lymphoproliferative disorders with pseudocarcinomatous hyperplasia are associated with a T-helper-17 cytokine profile and infiltrating granulocytes. J. Am. Acad. Dermatol. 72: 508-515.http://dx.doi.org/10.1016/j.jaad.2014.11.021

Hu X, Wang Y, Hao LY, Liu X, et al. (2015). Sterol metabolism controls T(H)17 differentiation by generating endogenous ROR $\gamma$ agonists. Nat. Chem. Biol. 11: 141-147. http://dx.doi.org/10.1038/nchembio.1714

Huang JN, Tsai MC, Fang SL, Chang MD, et al. (2014). Low-molecular-weight heparin and unfractionated heparin decrease Th-1, 2, and 17 expressions. PLoS One 9: e109996. http://dx.doi.org/10.1371/journal.pone.0109996

Kashem SW, Igyártó BZ, Gerami-Nejad M, Kumamoto Y, et al. (2015). Candida albicans morphology and dendritic cell subsets determine Thelper cell differentiation. Immunity 42:356-366.http://dx.doi.org/10.1016/j.immuni.2015.01.008 
Li Q, Wang Y, Li H, Shen G, et al. (2014). Ox-LDL influences peripheral Th17/Treg balance by modulating Treg apoptosis and Th17 proliferation in atherosclerotic cerebral infarction. Cell. Physiol. Biochem. 33: 1849-1862. http://dx.doi. org $/ 10.1159 / 000362963$

Lu ZH, Huang XP, Sun W, Zhu YL, et al. (2014). T helper cell dysregulation with hepatitis B and rebalance with glucocorticoids. World J. Gastroenterol. 20: 18354-18359. http://dx.doi.org/10.3748/wjg.v20.i48.18354

Munari F, Fassan M, Capitani N, Codolo G, et al. (2014). Cytokine BAFF released by Helicobacter pylori-infected macrophages triggers the Th17 response in human chronic gastritis. J. Immunol. 193: 5584-5594. http://dx.doi. org/10.4049/jimmunol.1302865

Muntner P, Anderson A, Charleston J, Chen Z, et al.; Chronic Renal Insufficiency Cohort (CRIC) Study Investigators (2010). Hypertension awareness, treatment, and control in adults with CKD: results from the Chronic Renal Insufficiency Cohort (CRIC) Study. Am. J. Kidney Dis. 55: 441-451.http://dx.doi.org/10.1053/j.ajkd.2009.09.014

Nie J, Li YY, Zheng SG, Tsun A, et al. (2015). FOXP3+ Treg cells and gender bias in autoimmune diseases. Front. Immunol. 6: 493.

Paul SK, Muinuddin G, Jahan S, Begum A, et al. (2014). Long versus standard initial prednisolone therapy in children with idiopathic nephrotic syndrome. Mymensingh Med. J. 23: 261-267.

Qiu MY, Xie QF, Wang LN and Yu L (2015). [Association between angiotensin-converting enzyme 2 gene polymorphisms and childhood primary nephrotic syndrome]. Zhongguo Dang Dai Er Ke Za Zhi 17: 232-236.

Ramesh R, Kozhaya L, McKevitt K, Djuretic IM, et al. (2014). Pro-inflammatory human Th17 cells selectively express P-glycoprotein and are refractory to glucocorticoids. J. Exp. Med. 211: 89-104. http://dx.doi.org/10.1084/ jem.20130301

Ruan Y, Huang H, Qin W, Qiu Y, et al. (2012). A study on the relationship between urine protein excretion and humoral immunity function in children with primary nephrotic syndrome. Med. Inf. 25: 73-74.

Said A, Bock S, Lajqi T, Müller G, et al. (2014). Chloroquine promotes IL-17 production by CD4+ T cells via p38dependent IL-23 release by monocyte-derived Langerhans-like cells. J. Immunol. 193: 6135-6143. http://dx.doi. org/10.4049/jimmunol.1303276

Shao XS, Yang XQ, Zhao XD, Li Q, et al. (2009). The prevalence of Th17 cells and FOXP3 regulate T cells (Treg) in children with primary nephrotic syndrome. Pediatr. Nephrol. 24: 1683-1690. http://dx.doi.org/10.1007/s00467-009-1194-x

Tabarkiewicz J, Pogoda K, Karczmarczyk A, Pozarowski P, et al. (2015). The Role of IL-17 and Th17 Lymphocytes in Autoimmune Diseases. Arch. Immunol. Ther. Exp. (Warsz.) 63: 435-449. http://dx.doi.org/10.1007/s00005-015-0344-z

Theron AJ, Steel HC, Tintinger GR, Feldman C, et al. (2013). Can the anti-inflammatory activities of $\beta 2$-agonists be harnessed in the clinical setting? Drug Des. Devel. Ther. 7: 1387-1398. http://dx.doi.org/10.2147/DDDT.S50995

Turner JE, Paust HJ, Steinmetz OM, Peters A, et al. (2010). CCR6 recruits regulatory T cells and Th17 cells to the kidney in glomerulonephritis. J. Am. Soc. Nephrol. 21: 974-985.http://dx.doi.org/10.1681/ASN.2009070741

Yang $J$ and Zhang BL (2015). [Value of determination of haptoglobin and $\alpha 1$-antitrypsin in predicting response to glucocorticoid therapy in children with primary nephrotic syndrome]. Zhongguo Dang Dai Er Ke Za Zhi 17: 227-231.

Wang L, Li Q, Wang LJ and Li X (2010). [Level of Th17 cell and CD4(+);CD25(+); Foxp3(+); regulatory T cell in peripheral blood mononuclear cells of primary nephrotic syndrome in children]. Xibao Yu Fenzi Mianyixue Zazhi 26: 783-786.

Wang L, Li Q, Wang L, Li C, et al. (2013). The role of Th17/IL-17 in the pathogenesis of primary nephrotic syndrome in children. Kidney Blood Press. Res. 37: 332-345. http://dx.doi.org/10.1159/000350161

Working Group for National Survey on Status of Diagnosis and Treatment of Childhood Renal Diseases (2014). [Multicenter survey of diagnostic and therapeutic status in Chinese childhood patients with steroid-sensitive, relaping/steroid-dependent nephrotic syndrome]. Zhonghua Er Ke Za Zhi 52: 194-200.

Yu XP, Guo RY, Su ML, Ming DS, et al. (2013). Dynamic changes of treg and th17 cells and related cytokines closely correlate with the virological and biochemical response in chronic hepatitis $b$ patients undergoing nucleos $(\mathrm{t})$ ide analogues treatment. Hepat. Mon. 13: e15332.http://dx.doi.org/10.5812/hepatmon.15332

Zambrano-Zaragoza JF, Romo-Martínez EJ, Durán-Avelar Mde J, García-Magallanes N2, et al. (2014). Th17 cells in autoimmune and infectious diseases. Int. J. Inflam. 2014; 2014: 651503.

Zhang J, Ke KF, Liu Z, Qiu YH, et al. (2013). Th17 cell-mediated neuroinflammation is involved in neurodegeneration of aß1-42-induced Alzheimer's disease model rats. PLoS One 8: e75786. http://dx.doi.org/10.1371/journal. pone. 0075786

Zhang L, Qian W, Chen Q, Yin L, et al. (2014a). Imbalance in circulating T lymphocyte subsets contributes to Hu antibodyassociated paraneoplastic neurological syndromes. Cell. Immunol. 290: 245-250. http://dx.doi.org/10.1016/j. cellimm.2014.06.009

Zhang X, Wu X, Xiong L, Yi Z, et al. (2014b). Role of vitamin D3 in regulation of T helper cell 17 and regulatory T-cell balance in rats with immunoglobulin a nephropathy. Iran. J. Kidney Dis. 8: 363-370. 